\title{
Does Paternal Methamphetamine Exposure Affect the Behavior of Rat Offspring During Development and in Adulthood?
}

\author{
Lýdia MIHALČÍKOVÁ ${ }^{1}$, Anna OCHOZKOVÁ ${ }^{1}$, Romana ŠLAMBEROVÁ ${ }^{1}$ \\ ${ }^{1}$ Department of Physiology, Third Faculty of Medicine, Charles University, Prague, Czech Republic
}

Received April 18, 2021

Accepted October 11, 2021

\begin{abstract}
Summary
Methamphetamine (MA) is one of the most abused psychostimulants in the Czech Republic and worldwide. Previous studies have demonstrated the adverse effects of maternal drug abuse. However, the father's contribution as a parent and donor of the half genetic information is unclear. The present study aimed to examine the effect of paternal MA exposure on behavioral development and locomotor activity in rat offspring. MA was administrated subcutaneously for 30 days at a dose of $5 \mathrm{mg} / \mathrm{kg}$ to adult male rats. The impact of paternal MA exposure on rat pups was investigated using behavioral tests during development and locomotor activity tests in adulthood. Prior to testing, adult offspring were exposed to an acute challenge dose of MA ( $1 \mathrm{mg} / \mathrm{kg}$ ) to examine the possible sensitizing effect of the paternal treatment. Our results found no significant differences in behavioral development or locomotor activity in adulthood of offspring linked to paternal MA application. These results differ from the effects induced by maternal MA application. Further, our results demonstrated a significant increase in locomotor activity on the Laboras test after acute MA application. When comparing sex differences, females showed more activity than males in adulthood, whereas males were more active during development.
\end{abstract}

\section{Key words}

Paternal exposure - Methamphetamine - Locomotor activity • Sensorimotor development • Drug abuse

\section{Corresponding author}

R. Šlamberová, Department of Physiology, Third Faculty of Medicine, Charles University, Ke Karlovu 458/4, 12000 Prague, Czech Republic. E-mail: romana.slamberova@lf3.cuni.cz

\section{Introduction}

Methamphetamine (MA), a highly potent psychostimulant, is one of the most accessible drug in the Czech Republic as well as worldwide. Psychostimulant drugs activate dopaminergic and serotoninergic pathways in the central nervous system, which are mainly involved in reward circuits, affective states, sexual behavior, and control of motor function and cognition. In humans, MA induces feelings of happiness and pleasure, suppresses anxiety and depression, increases concentration, reduces appetite, and promotes weight loss. It is known as a powerfully addictive drug, and due to its low price and relatively simple production has become increasingly popular in our society. In 2017, statistical surveys by EMCDDA (European Monitoring Centre for Drugs and Drug Addiction) reported 34,700 active MA users in the Czech Republic. The annual report of EMCDDA in 2019 reported that MA was the $4^{\text {th }}$ most abused illegal drug in the Czech Republic after cannabinoids, ecstasy, and hallucinogenic fungus (psilocybin). MA users are mostly men of reproductive age between 15 and 34 years. However, most recent studies looked at the impact of maternal MA abuse since MA crosses the placenta and is secreted into maternal breast milk; therefore, it can directly influence fetal brain development (Smith et al. 2008).

Our previous studies showed that MA administration to pregnant female rats affects the sensorimotor development of pups during the pre-weaning period (Hrubá et al. 2009, Šlamberová et al. 2006), evokes anxiety-like behavior in offspring (Schutová et al. 2009), affects offspring learning abilities (Macúchová et al. 2013), and leads to increased 
susceptibility to drug sensitization in adulthood (Šlamberová et al. 2009). Alterations in behavioral patterns manifested in social behavior in adolescence (Ševčíková et al. 2020) as well as in aggressive and sexual behavior in adulthood (Hol et al. 1999). MA exposure is also associated with increased physiological stress, decreased arousal, and poor quality of movement during the first five days of life (LaGasse et al. 2011, Smith et al. 2008). Maternal-focused research has resulted in significant advances. However, the contribution of rat fathers on the behavior and development of offspring has not yet been thoroughly studied. Despite that, in the last decade, the role of paternal drug exposure and its influence on offspring has gained more attention.

Psychostimulant drugs such as cocaine, amphetamines, cannabinoids may cause adverse effects on the quality and quantity of sperm and result in infertility of drug users (Verstegen et al. 2020). Few studies have examined paternal cocaine and cannabinoid effects on rat pup development and behavior in adulthood, and no studies on the effects of MA. Abel et al. 1989 showed that paternal cocaine (another psychostimulant drug) administration increases hyperactivity behavior in rat pups. Surprisingly, the reported bodyweight of prenatally exposed offspring has been inconsistent, with increased, decreased as well as unaffected body weights reported in previous studies (Abel et al. 1989, Fischer et al. 2017, George et al. 1996, He et al. 2006, Killinger et al. 2012, White et al. 2016). According to neurocognitive outcomes, Le et al. (2017) showed that the offspring of addicted male rats had increased cocaine self-administration. A study by Dalterio et al. (1984) showed that paternal THC (delta-9tetrahydrocannabinol) exposure significantly impairs the development of rat pups. Another study by Levin et al. (2019) showed that paternal THC exposure does not significantly affect the health of the offspring, including litter size, sex ratio, pup birth weight, survival, and growth. However, it results in neurocognitive alterations and decreased attention in offspring in adulthood (Levin et al. 2019). Therefore, the present study's first aim was to investigate the effect of paternal MA exposure on sensorimotor development of rat pups and spontaneous behavior in adulthood.

Our previous studies showed that MA administration in adulthood increases overall activity, e.g. increased locomotion and exploratory behavior (Hrubá et al. 2012). Furthermore, the increased effect of MA in adulthood was even greater in animals prenatally exposed to maternal MA administration during gestation and corresponded with increased dopamine levels (Bubeníková-Valešová et al. 2009). Based on these findings, it appears that maternal MA exposure sensitizes progeny to the effect of a challenge dose of the same drug in adulthood, which supports our study showing increased MA-seeking behavior using the Conditioned place preference test (Šlamberová et al. 2011). As such, the second aim of this study was to determine whether a challenge dose of MA exposure can induce a similar sensitizing effect on rat behavior.

Thus, our study was designed to answer the following questions: (1) Did paternal MA exposure induce changes in the sensorimotor development of their pups or behaviors in adulthood?; (2) Did acute MA exposure influence behavioral changes in adult rats relative to prenatal drug exposure?; and (3) Were there sex differences in sensorimotor development and behaviors in adulthood?

\section{Methods}

All experimental procedures used in this study were approved by the Institutional Animal Care and Use Committee in agreement with the Czech Government Requirements under the Policy of Human Care of Laboratory Animals (No. 246/1992) and subsequent regulations of the Ministry of Agriculture of the Czech Republic (No. 311/1997).

\section{Animals}

Forty adult male and 40 female Albino Wistar rats were purchased from Velaz (Prague, Czech Republic, bread by Charles River Laboratories International, Inc). Males (300-350 g) were housed three per cage, and females (250-300 g) were housed four per cage. All animals were left undisturbed for one week for acclimation in a temperature-controlled $\left(22-24^{\circ} \mathrm{C}\right)$ colony room. Animals had free access to food and water and were on a 12-hour light/12-hour dark cycle with lights on at 6:00 a.m. After the acclimation period, adult males were randomly assigned to the methamphetaminetreated (MA) group or the saline-treated (SA) group. D-methamphetamine hydrochloride was administrated subcutaneously (s.c.) in a dose of $5 \mathrm{mg} / \mathrm{ml} / \mathrm{kg}$ for 30 days. This dose of MA induces similar behavioral changes as those seen in humans and has been routinely used in all our experiments (Šlamberová et al. 2005). The Control 
group was treated with an s.c. saline injection $(1 \mathrm{ml} / \mathrm{kg})$ at the same time and in the same number as the MA group. After 30 days of exposure, males were mated with nontreated females. After a week, females were separated from males and left undisturbed until the day of delivery, postnatal day (PD) 0 . On PD 1, the number of pups in each litter was adjusted to 12 (whenever possible, half males and half females).

\section{Behavioral experiments during development}

Pups from 20 MA litters and 20 saline litters were tested in the experiments described below. Averages from males and females from each MA or SA litters, respectively, were counted as one unit.

\section{Righting reflex on surface}

The surface righting reflex was tested daily on PD 1-12 (Altman and Sudarshan 1975, Hrubá et al. 2009, Ševčíková et al. 2017). Each pup was turned to a supine position, and the time that it took for the pup to right itself with all four paws contacting the surface of the testing table was recorded. A two-way ANOVA (Paternal treatment $\times$ Sex) with repeated measures (Days) was used to analyze differences in righting reflex. Differences were considered significant if $\mathrm{p}<0.05$.

\section{Negative geotaxis}

The Negative geotaxis test was performed on PD 9 (Altman and Sudarshan 1975, Hrubá et al. 2009, Ševčíková et al. 2017). Each pup was placed facing downward on a board inclined at a $30^{\circ}$ angle. Each animal was given three trials, and the best latency for turning to face up the board, i.e. $180^{\circ}$ turn, was recorded. If the pup slid off the board, it was returned to the starting position, i.e. facing down the board. A two-way ANOVA (Paternal treatment $\times$ Sex) was used to analyze the differences in negative geotaxis. The Bonferroni post hoc test was used for comparisons of ANOVA analyses. Differences were considered significant if $\mathrm{p}<0.05$.

\section{Bar holding test}

The Bar holding test was performed on PD 23 to examine the vestibular function and sensorimotor coordination. The rats needed to achieve and maintain balance on a narrow bar (Murphy et al. 1995, Hrubá et al. 2009, Ševčíková et al. 2017). A wooden bar $40 \mathrm{~cm}$ long with a diameter of $1 \mathrm{~cm}$ was suspended $8 \mathrm{~cm}$ above a soft, padded surface. The pup was placed on the bar while being held by the nape of its neck, and its forepaws were allowed to touch the bar. The time of the fore- and hind-limb grasping reflex, with a limit of $120 \mathrm{~s}$, was recorded. Animals were subjected to three consecutive trials. A two-way ANOVA (Paternal treatment $\times$ Sex) with repeated measures (Trials) was used to analyze the differences in performance of the Bar Holding Test. The Bonferroni post hoc test was used for comparisons of ANOVA analyses. Differences were considered significant if $\mathrm{p}<0.05$.

\section{Rotarod test}

The rotarod test was performed on PD 23 to examine the sensorimotor coordination and the dynamic postural reactions needed for maintaining balance on a rotating cylinder (Šlamberová et al. 2006, Hrubá et al. 2009, Ševčíková et al. 2017). Pups were placed on a rugged cylinder $(11.5 \mathrm{~cm}$ in diameter, rotating at a constant speed of $6 \mathrm{rpm}$ ) oriented in the opposite direction of cylinder rotation so that they could walk forward. The duration of balance on the rotarod was determined for $120 \mathrm{~s}$. Trials were repeated until the rats accomplished the task or until there were six failures. The overall number of falls was recorded. A two-way ANOVA (Paternal treatment $\times$ Sex) with repeated measures (Trials) was used to analyze the differences on Rotarod Test. The Bonferroni post hoc test was used for comparisons of ANOVA analyses. Differences were considered significant if $\mathrm{p}<0.05$.

On the PD 23, the pups were weaned and split into cages according to sex and left undisturbed until adulthood. In adulthood (PD 60-80), the Laboras test was performed to examine the behavior of adult male and female rats in an unknown environment.

\section{Laboras test}

The adult rats were tested in the Laboras apparatus (Metris B.V., Netherlands), a fully automated system for continuous behavior tracking of rodents. It consists of a triangular-shaped sensor platform connected to a computer. The platform transforms the mechanical vibrations from movements of the animal into electrical signals. Each movement pattern has its own unique frequency and amplitude, and thus separate behavioral categories can be easily distinguished and classified by the computer. Two weeks before testing, the light-dark cycle was reversed in the colony room (lights on at 6:00 p.m. for $12 \mathrm{~h}$ ). As behavior in females can differ depending on the phase of the estrous cycle, the phase of the cycle was determined from vaginal lavage smears and examined using light microscopy (Turner and Bagnara 1976). Prior to testing, animals were exposed to an acute 
dose of MA (1 mg/kg), SA (1 ml/kg), or SHAM (single injection) to probe the sensitizing effect of the treatment (MA or SA) and to determine the stress response after a single injection. The dose $1 \mathrm{mg} / \mathrm{kg}$ of MA was chosen because the dose produces a drug concentration in the plasma and brain that peaks 45-60 min after MA administration (Bubeníková-Valešová et al. 2009) but does not induce stereotypical behavior in adult rats (Schutová et al. 2010). Testing took place from 12 p.m. to 6 p.m. in a darkened room. Before testing, each animal was weighed and moved to the testing room, where it remained in its home cage for $30 \mathrm{~min}$ to acclimate. The following experimental groups were tested:

Table 1. Experimental groups.

\begin{tabular}{|c|c|c|c|c|}
\hline Paternal treatment & Acute treatment in & & Sex & \\
\hline \multirow{3}{*}{$M A(5 \mathrm{mg} / \mathrm{ml} / \mathrm{kg})$} & MA (1 mg/kg) & Males & $\begin{array}{c}\text { Females } \\
\text { (estrus/proestrus) }\end{array}$ & $\begin{array}{c}\text { Females } \\
\text { (diestrus/metestrus) }\end{array}$ \\
\hline & $\mathrm{SA}(1 \mathrm{mg} / \mathrm{kg})$ & Males & $\begin{array}{c}\text { Females } \\
\text { (estrus/proestrus) }\end{array}$ & $\begin{array}{c}\text { Females } \\
\text { (diestrus/metestrus) }\end{array}$ \\
\hline & SHAM & Males & $\begin{array}{c}\text { Females } \\
\text { (estrus/proestrus) }\end{array}$ & $\begin{array}{c}\text { Females } \\
\text { (diestrus/metestrus) }\end{array}$ \\
\hline \multirow{3}{*}{$S A(1 \mathrm{ml} / \mathrm{kg})$} & MA (1 mg/kg) & Males & $\begin{array}{c}\text { Females } \\
\text { (estrus/proestrus) }\end{array}$ & $\begin{array}{c}\text { Females } \\
\text { (diestrus/metestrus) }\end{array}$ \\
\hline & $\mathrm{SA}(1 \mathrm{mg} / \mathrm{kg})$ & Males & $\begin{array}{c}\text { Females } \\
\text { (estrus/proestrus) }\end{array}$ & $\begin{array}{c}\text { Females } \\
\text { (diestrus/metestrus) }\end{array}$ \\
\hline & SHAM & Males & $\begin{array}{c}\text { Females } \\
\text { (estrus/proestrus) }\end{array}$ & $\begin{array}{c}\text { Females } \\
\text { (diestrus/metestrus) }\end{array}$ \\
\hline
\end{tabular}

Each animal was tested separately in the Laboras cage for $1 \mathrm{~h}$. The 1 -hour period was divided into six consecutive 10-minute intervals to evaluate the habituation of the animals. The following parameters were automatically evaluated: time spent in locomotion (s), time spent immobile (s), time spent rearing (s), time spent grooming (s), distance traveled $(\mathrm{m})$, and average speed $(\mathrm{mm} / \mathrm{s})$.

Each measured parameter was evaluated separately using a three-way ANOVA (Paternal treatment $\times$ Acute treatment $\times$ Sex) with repeated measures (Intervals). The experiment was analyzed using STATISTICA software. The Bonferroni test was used for post hoc comparisons. Differences were considered significant if $\mathrm{p}<0.05$.

\section{Results}

Righting reflex on surface

No significant differences were found between MA- and SA-treated groups of pups on any of the test days (PD 1-12). As shown in Figure 1, righting reflex on surface determinates significant sex differences
$\left[\mathrm{F}_{(1,229)}=5.98, \mathrm{p}<0.05\right]$. Male pups were faster in righting than female pups on PD 2.

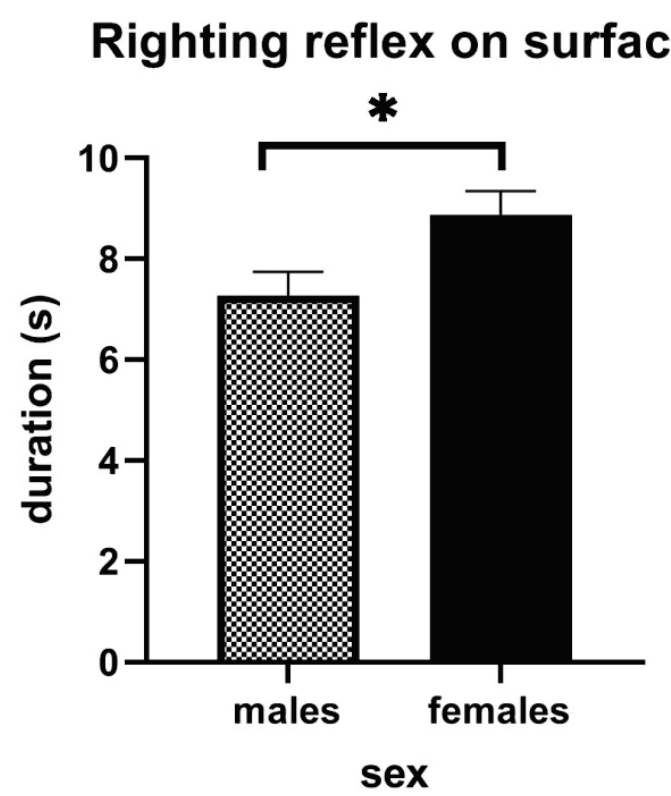

Fig. 1. Sex difference in righting reflex on a surface on the second postnatal day. Values represent the time [s] required for rotating from the supine to the on all four paws position and are shown as means \pm SEM $(n=8) . * p<0.05$. 


\section{Bar holding test}

No differences in time spent on the narrow bar were shown between MA- and SA- treated groups of pups on PD 23. As shown in Figure 2, the bar holding test indicates significant sex differences on the first and second trials of the test. Males had worse performance on the test compared to females $\left[\mathrm{F}_{(2,458)}=3.66, \mathrm{p}<0.05\right]$.

\section{Bar holding}

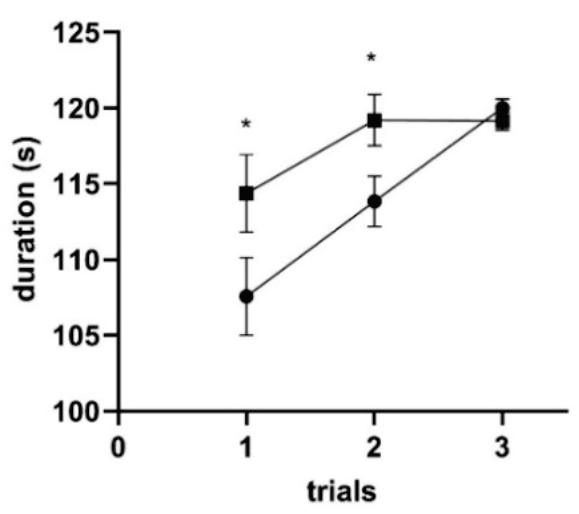

Fig. 2. Sex differences in bar holding test on PD 23. The graph shows the time $[\mathrm{s}]$ that animals endure to balance on the bar. Values are means $\pm \operatorname{SEM}(n=8) . * p<0.05$.

\section{Negative geotaxis}

Paternal MA administration or gender did not induce any significant differences in negative geotaxis on PD 9.

\section{Rotarod test}

The rotarod test did not show any significant differences in the time spend on the rotating cylinder between MA- and SA-treated pups on PD 23. The test did not show any sex differences between groups.

\section{Laboras test}

As shown in Figure 3, acute MA exposure significantly increased locomotor activity $\left[\mathrm{F}_{(10,660)}=14.34\right.$, $\mathrm{p}<0.0001]$, increased average speed $\left[\mathrm{F}_{(10,660)}=9.89\right.$, $\mathrm{p}<0.0001]$, increased distance traveled $\left[\mathrm{F}_{(10,660)}=9.89\right.$, $\mathrm{p}<0.0001]$, increased rearing $\left[\mathrm{F}_{(10,660)}=30.62, \mathrm{p}<0.0001\right]$, and decreased immobility $\left[\mathrm{F}_{(10,660)}=12.58, \mathrm{p}<0.0001\right]$ relative to control groups. In addition, our results show that SA-treated animals had decreased locomotor activity $\left[\mathrm{F}_{(2,132)}=19.61, \quad \mathrm{p}<0.0001\right]$ relative to SHAM-injected offspring in both prenatally exposed groups but only within the first 10-minute interval of the Laboras test. Moreover, SA-treated offspring showed increased immobility $\left[\mathrm{F}_{(2,132)}=55.15, \quad \mathrm{p}<0.0001\right]$ relative to SHAM-injected animals in the prenatally SA-treated group but only within the 40-50 minute interval of Laboras session. No differences were found in any of the parameters of Laboras test regarding the effect of paternal MA exposure on locomotor activity of offspring.

As shown in Figure 4, sex differences were observed after acute MA administration in locomotor activity, average speed, rearing, and distance travelled. Our results indicate that MA-treated males had decreased locomotion $\left[\mathrm{F}_{(4,132)}=2.69, \mathrm{p}<0.05\right]$, decreased average speed $\left[\mathrm{F}_{(4,132)}=4.01, \mathrm{p}<0.01\right]$, decreased distance traveled $\left[\mathrm{F}_{(4,132)}=4.01, \mathrm{p}<0.01\right]$, and decreased rearing activity $\left[\mathrm{F}_{(4,132)}=3.79, \mathrm{p}<0.01\right]$ relative to females regardless of their estrous cycle. Additionally, sex differences were also found in grooming. SHAM-injected males spent more time grooming $\left[\mathrm{F}_{(4,132)}=2.52, \quad \mathrm{p}<0.05\right] \quad$ compared to SHAM-injected females regardless of estrous cycle.

\section{Discussion}

The present study examined whether prenatal paternal MA administration causes similar postnatal consequences in offspring development compared to those found in previous studies with prenatal maternal MA exposure. While maternal MA exposure significantly impairs sensorimotor functions during development and affects locomotor activity in adulthood of prenatally exposed offspring (Šlamberová et al. 2006, Šlamberová et al. 2007 Hrubá et al. 2009, Schutová et al. 2013), paternal MA exposure does not seem to induce serious, long-lasting effects.

The present study's data did not show any effects of paternal MA exposure on sensorimotor development in the Righting reflex on a surface, Negative geotaxis, Bar holding test, or Rotarod test. These results are in contrast to the effects induced by maternal MA exposure, which showed that maternal MA exposure slowed down the surface righting reflex on PD 1-5 (Hrubá et al. 2008, Šlamberová et al. 2007, Malinová-Ševčíková et al. 2014), did not change the Negative geotaxis on PD 9 (MalinováŠevčíková et al. 2014), impaired performance on the Rotarod, but not Bar holding on PD 23. Thus, it seems that paternal MA exposure does not influence sensorimotor development of rat pups as does maternal MA exposure. The explanation may be that while maternal exposure can directly affect the development of pups since MA crosses the placenta and enters breast milk during lactation (Dattel 1990, Rambousek et al. 2014), paternal exposure would need a genetic change in the pup, which does not appear to occur. 
Locomotor activity- prenatal treatment SA

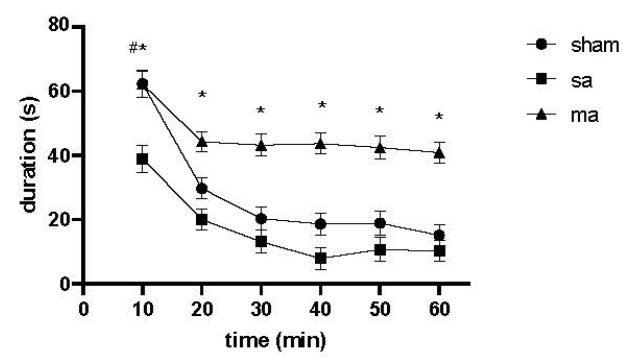

Average speed- prenatal treatment SA

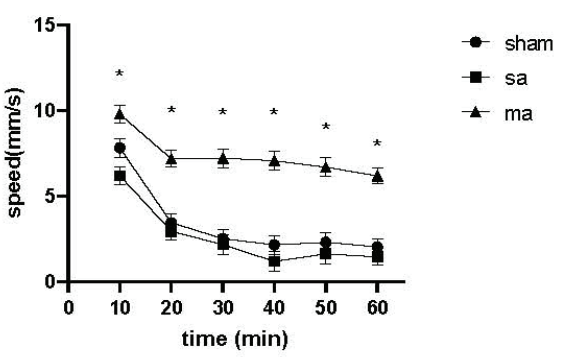

Distance traveled-prenatal treatment SA

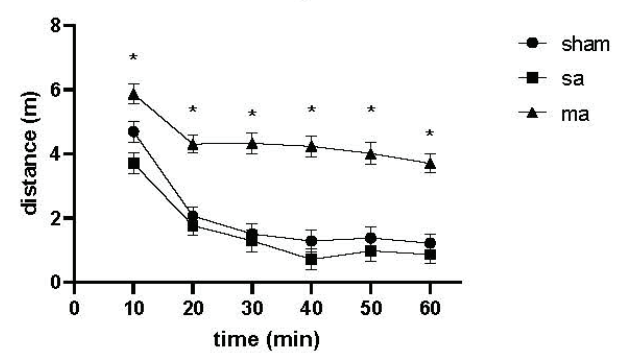

Rearing-prenatal treatment SA

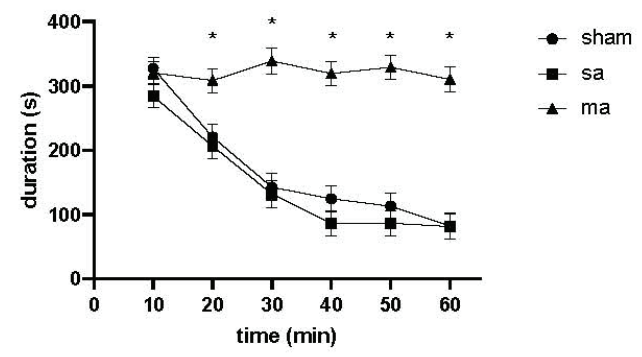

Immobility- prenatal treatment SA

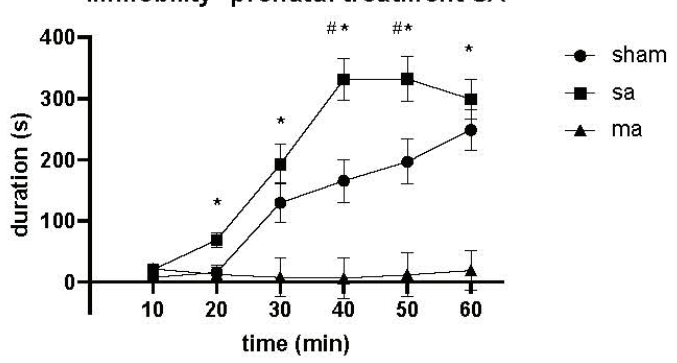

Locomotor activity- prenatal treatment MA

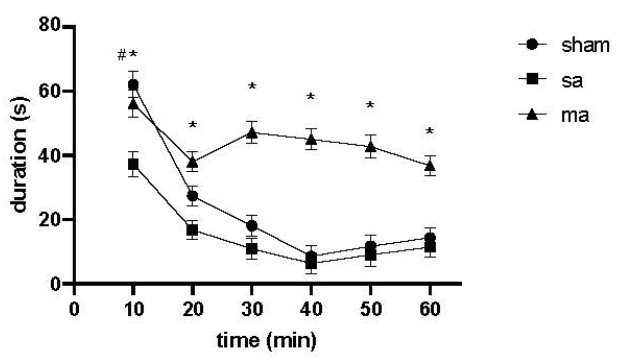

Average speed- prenatal treatment MA

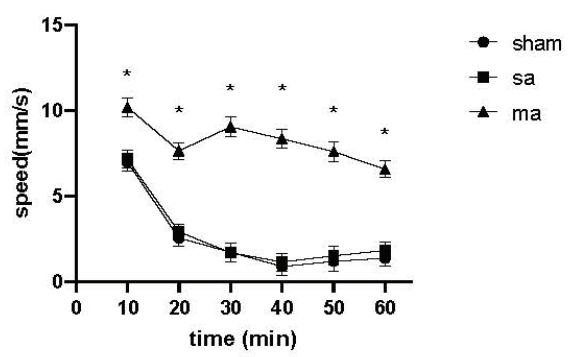

Distance traveled-prenatal treatment MA

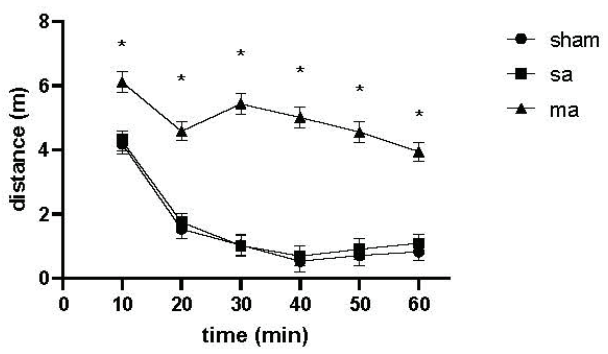

Rearing-prenatal treatment MA

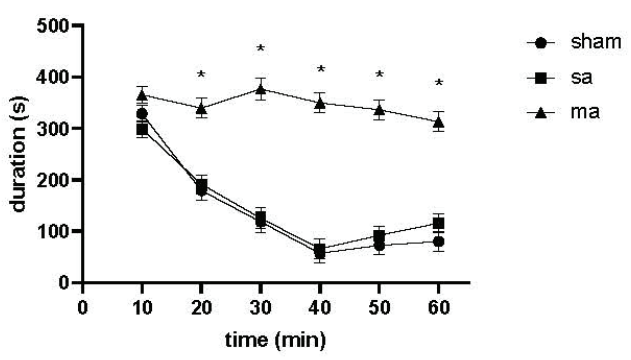

Immobility- prenatal treatment MA

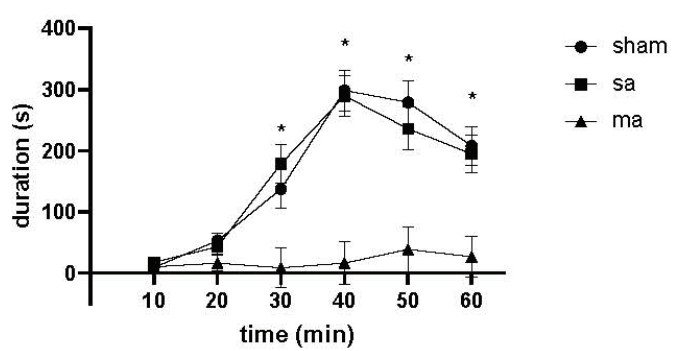

Fig. 3. The effect of prenatal and acute $M A$ exposure on locomotor activity of offspring in the Laboras test. MA=methamphetamine, SA-saline, SHAM-single injection. Values are mean \pm SEM $(n=8) . * p<0.05$ acute MA $>$ acute SA, SHAM; ${ }^{*} p<0.05$ acute SA<acute SHAM (locomotion); ${ }^{\#} \mathrm{p}<0.05$ acute SA $>$ acute SHAM (immobility). 
Locomotor activity- acute treatment /sex

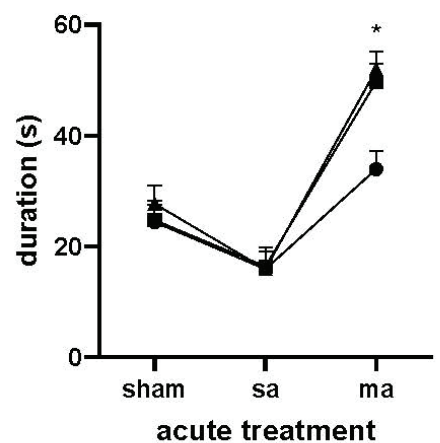

acute treatment

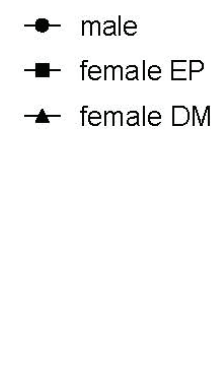

Average speed- acute treatment/sex

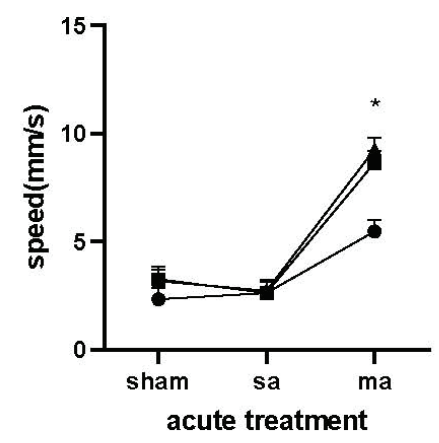

$\rightarrow$ male

-r female EP

- female DM

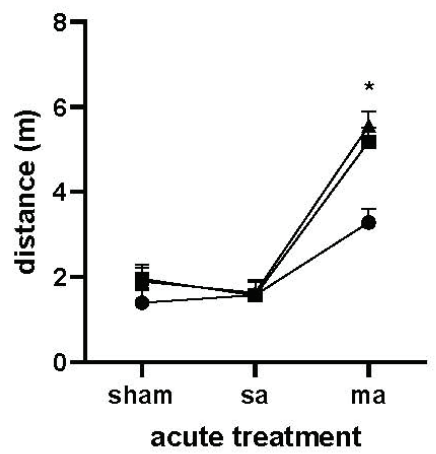

\section{Distance traveled-acute treatment/sex}

acute treatment
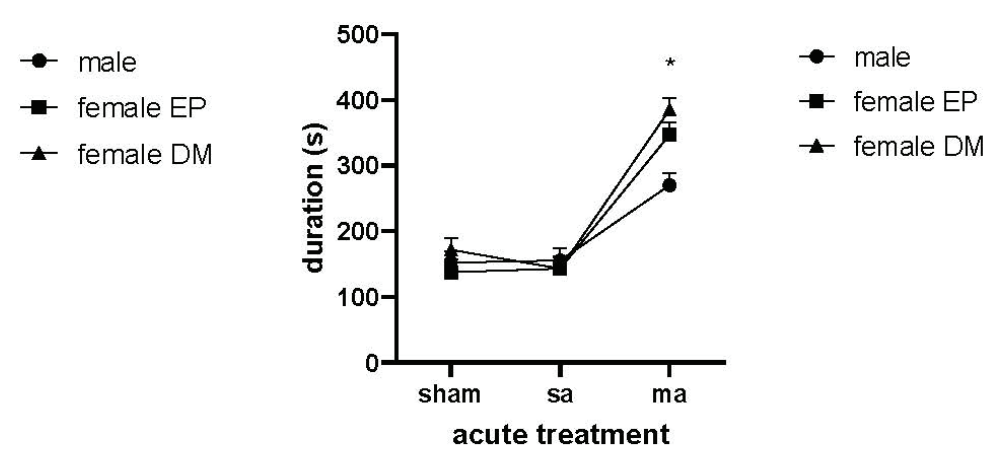

Grooming- acute treatment/sex

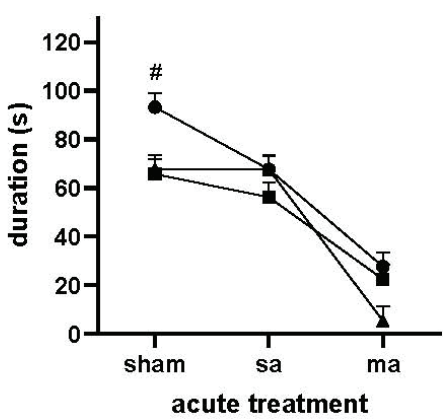

$\rightarrow$ male

- female EP

$\star$ female DM

Fig. 4. Sex differences in locomotor activity after acute $M A$ exposure of offspring in Laboras test. $M A=$ methamphetamine, $S A=$ saline, SHAM $=$ single injection. Values are mean \pm SEM $(n=8)$. ${ }^{*} p<0.05$ males<females (MA administration); ${ }^{*} p<0.05$ males $>$ females (SHAM injection).

The studies of paternal MA exposure and its consequences on the development of offspring are not entirely complete. Recently, there has been a lack of relevant studies that could provide a comparison with our results. Therefore, in this study, we tried to analyze and compare our data to previous studies that focused on maternal MA exposure and paternal exposure to different psychoactive drugs (such as cocaine, cannabinoids, or alcohol). Abel et al. (1989) determined that paternal cocaine administration did not affect litter size or birth weight but resulted in pup hyperactivity. A work by Lam et al. (2000) indicates lower weight gain and increased latency to right themselves in pups from prenatally alcohol-exposed rats relative to the controls. A study by 
Dalterio et al. (1984) showed reduced litter size and as well as increased pre- and postnatal mortality in cocaineexposed rat offspring. However, there are no studies that examine the sensorimotor development of offspring after paternal MA exposure.

The Laboras test data demonstrates that paternal MA exposure does not affect locomotor activity and exploratory behavior of offspring in adulthood. Because no studies have investigated the effect of paternal MA exposure, we have to compare our results with the effects of other drugs. However, these studies are inconsistent in their outcomes. Similarly, with our results, a study by Killinger et al. (2012) showed that spontaneous locomotor activity after paternal cocaine exposure was unaffected. A study by Fisher et al. (2017) reported increased locomotor activity after paternal cocaine exposure, and a study by Levin et al. (2019) showed that paternal THC treatment does not affect spontaneous locomotion of offspring, although it increases habituations during locomotor activity. In addition, another study with paternal alcohol exposure showed that locomotor activity of offspring increased by $30 \%$ compared to controls (Ledig et al. 1998). However, our data found no differences in locomotor activity of offspring after paternal MA administration.

To answer the question of acute MA administration relative to paternal MA exposure, our data showed that acute MA administration increased overall activity in the Laboras cage as demonstrated by increased locomotor activity, rearing, average speed, distance traveled, and decreased immobility. However, this effect was not dependent on paternal MA exposure. Our findings agree with our previous studies (Hrubá et al. 2012, Šlamberová et al. 2014), which demonstrated that maternal MA exposure during gestation did not affect the baseline level of locomotor and exploratory behavior in adult offspring. Further, and in agreement with other studies (Glatt et al. 2000, Hall et al. 2008, Schutová et al. 2010), acute MA application of $1 \mathrm{mg} / \mathrm{kg}$ increased overall activity on the Laboras test. The increased locomotor activity after acute MA exposure is mainly associated with increased levels of dopamine, especially in the nucleus accumbens (Bubeníková-Valešová et al. 2009). However, while maternal MA exposure seems to sensitize the offspring to the effect of the same drug in adulthood (Bubeníková-Valešová et al. 2009), the same seems not to be true in paternal MA exposure. Only one study by Fisher et al. (2017) reported increased locomotor sensitivity induced by paternal cocaine exposure to acute cocaine and amphetamine doses. Apart from the effect of acute MA administration, our data showed that saline injections significantly decreased locomotor activity relative to SHAM-injected rats, but only during the first $10 \mathrm{~min}$ of the experiment. Moreover, SA-treated offspring showed increased immobility relative to SHAM-injected animals within the 40-50 minute intervals of the Laboras test. The explanation for this finding may be that the injection itself, regardless of the injected solution or drug, induces behavioral changes in animals in an unknown environment (Šlamberová et al. 2018), which may be associated with the stress reaction and activation of the hypothalamic-pituitary-adrenal axis (Gomez and GarciaGarcia 2017).

The present study is exceptional because it tests the effects of drugs on both sexes during development and in adulthood. Most behavioral studies only examine males. The current data showed sex differences in tests performed during development as well as in adult rats. When examining sensorimotor development, male rats were faster at righting on the second postnatal day than females. In contrast, females were more capable of balancing on the narrow bar than males and achieved a better score on the bar holding test on the first and second testing trial. There were no sex differences in Negative geotaxis or the Rotarod test. Based on our data, males are faster, while females are better at maintaining balance. The sex differences relative to test performance can be caused both by the age at which the test was performed and because males and females differ in the development of sensorimotor skills. Tests used in our study revealed different skills. While the righting reflex on a surface on PD 1-12 examines tactile maturation of motor skills of pups and is under control of the brain stem (Pellis and Pellis 1994), the Negative geotaxis test examined on PD 9 is an automatic, stimulus-bound orientation movement considered diagnostic of vestibular and proprioceptive function (de Castro et al. 2007). The Rotarod and Bar holding tests examined on PD 23 are related to sensorimotor development that requires fully developed cerebellar coordination (Murphy et al. 1995).

Sex differences were also observed during the Laboras experiment when an acute dose of MA was administrated. Our data showed that MA-treated males were significantly less active, as demonstrated by decreased locomotor activity, rearing, average speed, and distance traveled relative to females regardless of the estrous cycle. There is considerable evidence for gender 
differences in psychostimulant drug abuse (Becker et al. 1982, Dluzen and Liu 2008, Cox et al. 2013, Reichel et al. 2012, Hrubá et al. 2012). In rodents, acute or chronic treatment with psychostimulants results in higher locomotor activity in females than males (Becker 1999. Bisagno et al. 2003, Páleníček et al. 2005). In addition, a study by Milesi-Hallé et al. (2007) demonstrated that MA-treated females show greater and longer-lasting locomotor activity relative to males. Thus, our findings that acute MA exposure impairs locomotor activity in males compared with females agree with previous studies.

In conclusion, our results show that paternal MA administration does not affect sensorimotor development of offspring. Our findings also indicate that MA abuse in rat fathers does not influence the locomotor activity and exploratory behavior of their adult offspring.
Although we did not find any significant effects of paternal MA exposure, our study is the first to determine whether paternal MA exposure had similar adverse effects on offspring development as maternal exposure.

\section{Conflict of Interest}

There is no conflict of interest.

\section{Acknowledgements}

This work was supported by research program Progres Q35, GAUK 1442120, and 260533/SVV/2021 from Charles University. This work was further supported by the ERDF/ESF project "PharmaBrain" CZ.02.1.01/0.0/0.0/16_0250007444 funded from OP VVV. The authors express their appreciation to Thomas Secrest for editing the manuscript.

\section{References}

ABEL EL: Paternal behavioral mutagenesis. Neurotoxicology 10: 335-345, 1989.

ALTMAN J, SUDARSHAN K: Postnatal development of locomotion in the laboratory rat. Anim Behav 23: 896-920, 1975. https://doi.org/10.1016/0003-3472(75)90114-1

BECKER JB, ROBINSON TE, LORENZ KA: Sex difference and estrous cycle variations in amphetamine-elicited rotational behavior. Eur J Pharmacol 80: 65-72, 1982. https://doi.org/10.1016/0014-2999(82)90178-9

BECKER JB: Gender differences in dopaminergic function in striatum and nucleus accumbens. Pharmacol Biochem Behav 64: 803-812, 1999. https://doi.org/10.1016/s0091-3057(99)00168-9

BISAGNO V, FERGUSON D, LUINE VN: Chronic D-amphetamine induces sexually dimorphic effects on locomotion, recognition memory, and brain monoamines. Pharmacol Biochem Behav 74: 859-867, 2003. https://doi.org/10.1016/s0091-3057(03)00017-0

BUBENIKOVA-VALESOVA V, KACER P, SYSLOVA K, RAMBOUSEK L, JANOVSKY M, SCHUTOVA B, SLAMBEROVA R: Prenatal methamphetamine exposure affects the mesolimbic dopaminergic system and behavior in adult offspring. Int J Dev Neurosci 27: 525-530, 2009. https://doi.org/10.1016/j.ijdevneu.2009.06.012

COX BM, YOUNG AB, SEE RE, REICHEL CM: Sex differences in methamphetamine seeking in rats: Impact of oxytocin. Psychoneuroendocrinology 38: 2343-2353, 2013. https://doi.org/10.1016/j.psyneuen.2013.05.005

DALTERIO S, STEGER R, MAYFIELD D, BARTKE A: Early cannabinoid exposure influences neuroendocrine and reproductive functions in mice: II. Postnatal effects. Pharmacol Biochem Behav 20: 115-123, 1984. https://doi.org/10.1016/0091-3057(84)90111-4

DATTEL BJ: Substance abuse in pregnancy. Semin Perinatol 14: 179-187, 1990.

DE CASTRO VL, DESTEFANI CR, DINIZ C, POLI P: Evaluation of neurodevelopmental effects on rats exposed prenatally to sulfentrazone. Neurotoxicology 28: 1249-1259, 2007. https://doi.org/10.1016/j.neuro.2007.06.001

DLUZEN DE, LIU B: Gender differences in methamphetamine use and responses: a review. Gend Med 5: 24-35, 2008. https://doi.org/10.1016/s1550-8579(08)80005-8

EUROPEAN MONITORING CENTRE FOR DRUGS AND DRUG ADDICTION: European drug report 2019: trends and developments. Office for Official Publications of the European Communities, 2019.

FISCHER DK, RICE RC, RIVERA AM, DONOHOE M, RAJADHYAKSHA AM: Altered reward sensitivity in female offspring of cocaine-exposed fathers. Behav Brain Res 332: 23-31, 2017. https://doi.org/10.1016/j.bbr.2017.05.054

GEORGE VK, LI H, TELOKEN C, GRIGNON DJ, LAWRENCE WD, DHABUWALA CB: Effects of long-term cocaine exposure on spermatogenesis and fertility in peripubertal male rats. J Urol 155: 327-331, 1996. 
GLATT SJ, BOLAÑOS CA, TRKSAK GH, CROWDER-DUPONT C, JACKSON D: Prenatal cocaine exposure alters behavioral and neurochemical sensitization to amphetamine in adult rats. Neuropharmacology 39: 599-610, 2000. https://doi.org/10.1016/s0028-3908(99)00181-1

GOMEZ F, GARCÍA-GARCÍA L: Anxiogenic-like effects of fluoxetine render adult male rats vulnerable to the effects of a novel stress. Pharmacol Biochem Behav 153: 32-44, 2017. https://doi.org/10.1016/j.pbb.2016.12.007

HALL DA, STANIS JJ, AVILA HM, GULLEY JM: A comparison of amphetamine-and methamphetamine-induced locomotor activity in rats: evidence for qualitative differences in behavior. Psychopharmacology 195: 469-478, 2008. https://doi.org/10.1007/s00213-007-0923-8

HE F, LIDOW IA, LIDOW MS: Consequences of paternal cocaine exposure in mice. Neurotoxicol Teratol 28: 198-209, 2006. https://doi.org/10.1016/j.ntt.2005.12.003

HOL T, VAN DEN BERG CL, VAN REE JM, SPRUIJT BM: Isolation during the play period in infancy decreases adult social interactions in rats. Behav Brain Res 100: 91-97, 1999. https://doi.org/10.1016/s0166-4328(98)00116-8

HRUBÁ L, SCHUTOVÁ B, ŠLAMBEROVÁ R, POMETLOVÁ M, ROKYTA R: Effect of methamphetamine exposure and cross-fostering on sensorimotor development of male and female rat pups. Dev Psychobiol 51: 73-83, 2009. https://doi.org/10.1002/dev.20346

HRUBÁ L, SCHUTOVÁ B, ŠLAMBEROVÁ R, POMETLOVÁ M: Does cross-fostering modify the impairing effect of methamphetamine on postnatal development of rat pups. Prague Med Rep 109: 50-61, 2008.

HRUBÁ L, SCHUTOVÁ B, ŠLAMBEROVÁ R: Sex differences in anxiety-like behavior and locomotor activity following prenatal and postnatal methamphetamine exposure in adult rats. Physiol Behav 105: 364-370, 2012. https://doi.org/10.1016/j.physbeh.2011.08.016

KILLINGER CE, ROBINSON S, STANWOOD GD: Subtle biobehavioral effects produced by paternal cocaine exposure. Synapse 66: 902-908, 2012. https://doi.org/10.1002/syn.21582

LAGASSE LL, WOULDES T, NEWMAN E, SMITH LM, SHAH RZ, DERAUF C, HUESTIS MA, ARRIA AM, DELLA GROTTA S, WILCOX T, LESTER BM: Prenatal methamphetamine exposure and neonatal neurobehavioral outcome in the USA and New Zealand. Neurotoxicol Teratol 33: 166-175, 2011. https://doi.org/10.1016/j.ntt.2010.06.009

LAM MK, HOMEWOOD J, TAYLOR AJ, MAZURSKI EJ: Second generation effects of maternal alcohol consumption during pregnancy in rats. Prog Neuropsychopharmacol Biol Psychiatry 24: 619-631, 2000. https://doi.org/10.1016/s0278-5846(00)00097-X

LE Q, YAN B, YU X, LI Y, SONG H, ZHU H, HOU W, MA D, WU F, ZHOU Y, MA L: Drug-seeking motivation level in male rats determines offspring susceptibility or resistance to cocaine-seeking behaviour. Nat Commun 8: 1-13, 2017. https://doi.org/10.1038/ncomms15527

LEDIG M, MISSLIN R, VOGEL E, HOLOWNIA A, COPIN JC, THOLEY G: Paternal alcohol exposure: developmental and behavioral effects on the offspring of rats. Neuropharmacology 37: 57-66, 1998. https://doi.org/10.1016/s00283908(97)00185-8

LEVIN ED, HAWKEY AB, HALL BJ, CAULEY M, SLADE S, YAZDANI E, KENOU B, WHITE H, WELLS C, REZVANI AH, MURPHY SK: Paternal THC exposure in rats causes long-lasting neurobehavioral effects in the offspring. Neurotoxicol Teratol 74, 2019. https://doi.org/10.1016/j.ntt.2019.04.003

MACÚCHOVÁ E, NOHEJLOVÁ-DEYKUN K, ŠLAMBEROVÁ R: Effect of methamphetamine on cognitive functions of adult female rats prenatally exposed to the same drug. Physiol Res 62 (Suppl 1): S89-S98, 2013. https://doi.org/10.33549/physiolres.932598

MALINOVÁ-ŠEVČÍKOVÁ M, HREBÍČKOVÁ I, MACÚCHOVÁ E, NOVÁ E, POMETLOVÁ M, ŠLAMBEROVÁ R: Differences in maternal behavior and development of their pups depend on the time of methamphetamine exposure during gestation period. Physiol Res 63 (Suppl 4): S559-S572, 2014. https://doi.org/10.33549/physiolres.932925

MILESI-HALLÉ A, MCMILLAN DE, LAURENZANA EM, BYRNES-BLAKE KA, OWENS SM: Sex differences in $(+)$-amphetamine-and $(+)$-methamphetamine-induced behavioral response in male and female Sprague-Dawley rats. Pharmacol Biochem Behav 86: 140-149, 2007. https://doi.org/10.1016/j.pbb.2006.12.018

MURPHY MP, RICK JT, MILGRAM NW, IVY GO: A simple and rapid test of sensorimotor function in the aged rat. Neurobiol Learn Mem 64: 181-186, 1995. https://doi.org/10.1006/nlme.1995.1057 
PALENICEK T, VOTAVA M, BUBENIKOVA V, HORACEK J: Increased sensitivity to the acute effects of MDMA ("ecstasy") in female rats. Physiol Behav 86: 546-553, 2005. https://doi.org/10.1016/j.physbeh.2005.08.043

PELLIS SM, PELLIS VC: Development of righting when falling from a bipedal standing posture: evidence for the dissociation of dynamic and static righting reflexes in rats. Physiol Behav 56: 659-663, 1994. https://doi.org/10.1016/0031-9384(94)90223-2

RAMBOUSEK L, KACER P, SYSLOVA K, BUMBA J, BUBENIKOVA-VALESOVA V, SLAMBEROVA R: Sex differences in methamphetamine pharmacokinetics in adult rats and its transfer to pups through the placental membrane and breast milk. Drug Alcohol Depend 139: 138-144, 2014. https://doi.org/10.1016/j.drugalcdep.2014.03.023

REICHEL CM, CHAN CH, GHEE SM, SEE RE: Sex differences in escalation of methamphetamine self-administration: cognitive and motivational consequences in rats. Psychopharmacology (Berl) 223: 371-380, 2012. https://doi.org/10.1007/s00213-012-2727-8

SCHUTOVÁ B, HRUBÁ L, POMETLOVÁ M, DEYKUN K, ŠLAMBEROVÁ R: Cognitive functions and drug sensitivity in adult male rats prenatally exposed to methamphetamine. Physiol Res 58: 741-750, 2009. https://doi.org/10.33549/physiolres.931562

SCHUTOVÁ B, HRUBÁ L, POMETLOVÁ M, ROKYTA R, ŠLAMBEROVÁ R: Responsiveness to methamphetamine in adulthood is altered by prenatal exposure in rats. Physiol Behav 99: 381-387, 2010. https://doi.org/10.1016/j.physbeh.2009.12.004

SCHUTOVÁ B, HRUBÁ L, ROKYTA R, ŠLAMBEROVÁ R: Gender differences in behavioral changes elicited by prenatal methamphetamine exposure and application of the same drug in adulthood. Dev Psychobiol 55: 232-242, 2013. https://doi.org/10.1002/dev.21016

ŠEVČÍKOVÁ M, HREBÍČKOVÁ I, MACÚCHOVÁ E, ŠLAMBEROVÁ R: The influence of methamphetamine on maternal behavior and development of the pups during the neonatal period. Int J Dev Neurosci 59: 37-46, 2017. https://doi.org/10.1016/j.ijdevneu.2017.03.005

ŠEVČÍKOVÁ M, PETříKOVÁ I, ŠLAMBEROVÁ R: Methamphetamine exposure during the first, but not the second half of prenatal development, affects social play behavior. Physiol Res 69: 319-330, 2020. https://doi.org/10.33549/physiolres.934230

S̆LAMBEROVÁ R, CHAROUSOVÁ P, POMETLOVÁ M: Methamphetamine administration during gestation impairs maternal behavior. Dev Psychobiol 46: 57-65, 2005. https://doi.org/10.1002/dev.20042

ŠLAMBEROVÁ R, MACÚCHOVÁ E, NOHEJLOVÁ K, ŠTOFKOVÁ A, JURČOVIČOVÁ J: Effect of amphetamine on adult male and female rats prenatally exposed to methamphetamine. Prague Med Rep 115: 43-59, 2014. https://doi.org/10.14712/23362936.2014.5

ŠLAMBEROVÁ R, MIKULECKÁ A, POMETLOVÁ M, SCHUTOVÁ B, HRUBÁ L, DEYKUN K: Sex differences in social interaction of methamphetamine-treated rats. Behav Pharmacol 22: 617-623, 2011. https://doi.org/10.1097/FBP.0b013e32834afea4

ŠLAMBEROVÁ R, NOHEJLOVÁ K, OCHOZKOVÁ A, MIHALČÍKOVÁ L: What is the role of subcutaneous single injections on the behavior of adult male rats exposed to drugs? Physiol Res 67 (Suppl 4): S665-S672, 2018. https://doi.org/10.33549/physiolres.934053

ŠLAMBEROVÁ R, POMETLOVÁ M, CHAROUSOVÁ P: Postnatal development of rat pups is altered by prenatal methamphetamine exposure. Progress Neuropsychopharmacol Biol Psychiatry 30: 82-88, 2006. https://doi.org/10.1016/j.pnpbp.2005.06.006

ŠLAMBEROVÁ R, POMETLOVÁ M, ROKYTA R: Effect of methamphetamine exposure during prenatal and preweaning periods lasts for generations in rats. Dev Psychobiol 49: 312-322, 2007. https://doi.org/10.1002/dev.20203

ŠLAMBEROVÁ R, SCHUTOVÁ B, MATĚJOVSKÁ I, BERNÁŠKOVÁ K, ROKYTA R: Effects of a single postnatal methamphetamine administration on NMDA-induced seizures are sex-and prenatal exposure-specific. Naunyn Schmiedebergs Arch Pharmacol 380: 109-114, 2009. https://doi.org/10.1007/s00210-009-0427-7

SMITH LM, LAGASSE LL, DERAUF C, GRANT P, SHAH R, ARRIA A, HUESTIS M, HANING W, STRAUSS A, DELlA GROTTA S, FALLONE M, LIU J, LESTER BM: Prenatal methamphetamine use and neonatal neurobehavioral outcome. Neurotoxicol Teratol 30: 20-28, 2008. https://doi.org/10.1016/j.ntt.2007.09.005 
TURNER CD, BAGNARA JT: Biological effects of the ovarian hormones. Gen Endocrinol 6: 466-476, 1976.

VERSTEGEN RH, WANG G, LANGENBERG-VERVERGAERT KP, REN LY, NULMAN I: Paternal exposure to recreational drugs before conception and its effect on live-born offspring: A scoping review. Birth Defects Res 112: 970-988, 2020. https://doi.org/10.1002/bdr2.1702

WHITE SL, VASSOLER FM, SCHMIDT HD, PIERCE RC, WIMMER ME: Enhanced anxiety in the male offspring of sires that self-administered cocaine. Addict Biol 21: 802-810, 2016. https://doi.org/10.1111/adb.12258 